\title{
Chapter 13 \\ Lille Metropolis: Co-production of Housing in a Major Urban Renewal District
}

\author{
Laurent Fraisse
}

\subsection{Introduction}

Union is the name of one of the biggest urban renewal projects in the RoubaixTourcoing-Wattrelot district (Lille Metropolis). In a post-industrial site spreading across 80 ha, a large project has been planned combining an eco-neighbourhood, a business hub and new housing, including $30 \%$ of social housing. In a district called Ilot Stephenson at the periphery of this area, a protest by inhabitants against the demolition of their popular housing led to an innovative housing co-production action between architects, local authorities and an inhabitants' organisation. Access to 30 homes at reduced cost has been achieved thanks to an innovative mode of architectural intervention that encourages inhabitants' participation in the self-rehabilitation of their neighbourhood. This emblematic initiative has inspired and has been integrated into the broader participative governance process of one of the most ambitious urban renewal projects in northern France.

This innovation-driven urban process has to be understood in the context of a long de-industrialisation process within the Lille Metropolitan area and the NordPas-de Calais region. This process has strongly affected the historical working class and inclusion in the labour market of new generations, who face high degrees of unemployment and a rise in social vulnerabilities. The area's industrial background has also impacted on the nature of housing, with a large stock of working-class houses, former blue-collar dormitories that have become de facto social housing. A lot of them have been left unused for many years and tend not to comply with health and safety regulations, with tenants living in very poor, even insalubrious conditions (inadequate heating system, substandard water supply, etc.). In this context, metropolitan urban policies have aimed at investing in urban renewal and housing construction to improve urban living conditions but also to promote economic regeneration. This urban renewal operation has been politically one of the significant

\footnotetext{
L. Fraisse ( $\square)$

90 rue de Bagnolet, 75020 Paris, France

e-mail: fraisse_laurent@orange.fr

(C) The Author(s) 2016
}

T. Brandsen et al. (eds.), Social Innovations in the Urban Context,

Nonprofit and Civil Society Studies, DOI 10.1007/978-3-319-21551-8_13 
projects launched and managed by the Lille Metropolis Urban Community (LMCU) which gathered 85 municipalities, large cities (Lille, Roubaix, Tourcoing) and their independent suburbs, and was governed by a left wing coalition between 2008 and 2014.

On a wider scale, the background to this innovation is a period of urban policies in the 2000s characterised by a vast national programme of urban renewal targeting deprived districts. Several hundred demolition-reconstruction operations covering large social housing complexes built during the 1960s and 1970s have taken place in the suburbs of France's big cities. Focusing mainly on the architectural and construction aspects, the role and participation of inhabitants in such urban renewal projects has often been the subject of controversy (Donzelot and Epstein 2006; Hall and Hickman 2011). The Ilot Stephenson initiative could be considered as a pilot project to test an alternative approach to urban renewal (Fraisse 2013). Architect Patrick Bouchain and his colleagues launched the concept Construisons ensemble, Le Grand ensemble [Working together to build the whole urban area], which was tested between 2009 and 2012 (Bouchain and David 2010).

\subsection{The Ilot Stephenson Rehabilitation}

The story of the Ilot Stephenson neighbourhood started with a conflict at the beginning of the 2000s when the inhabitants of this small working-class neighbourhood located at the periphery of the Union urban renewal project learnt that the municipality would purchase their houses and then demolish them. They organised themselves into an organisation named Rase pas mon quartier [Don't demolish my neighbourhood] and initiated actions protesting against the project with some support from various elected opposition members.

After several years, they succeeded in stopping the demolition project in 2004. In 2007, the Lille Metropolis authorities decided to transfer the management of the whole Union urban renewal development to the semi-public company, SEM Ville Renouvelée, with an obligation to properly integrate sustainable development and participatory approaches. After 3 years, during which nothing happened, the Ilot Stephenson project was the first operation launched in an atmosphere of mutual mistrust between inhabitants and urban planners. The mayor of Tourcoing and SEM Ville Renouvelée decided to call on architect Patrick Bouchain and his team to rethink the urban project with the inhabitants of the neighbourhood.

After a contentious atmosphere between inhabitants and local authorities, new ways of addressing inhabitants of the Stephenson neighbourhood emerged and opened up a new period of collaboration. An innovative architectural intervention based on participative and local co-production has led to the rehabilitation of 30 historical houses and the improvement of 24 inhabited houses. Of this, 12 have been purchased by a social landlord. Several have taken on a self-rehabilitation dimension and were sold at a lower price. In addition, architecture skills and urban project management were available for any owners or tenants making housing improvements (thermal and energetic diagnosis, insulation, etc.). 


\subsection{Approaches and Ways of Addressing Users}

The Ilot Stephenson project is a new architectural and urban planning experiment conceptualised by Patrick Bouchain and his architects' firm, Construire. They are part of the architectural movement that considers that building cities should not only be a matter for specialists (architects, urban planners, property developers, social landlords, etc.) and that inhabitants should not be passive subjects who are generally excluded from most social housing, construction and urban renewal projects. Inhabitants' participation in the production of social housing or rehabilitation of urban areas is one of the key principles for improving cohabitation in the city. In this context, the recent and systematic demolition-reconstruction incentives in France do not sufficiently take into account people's lives and the neighbourhood's history.

"Building is living" is one of the principles of a new interaction with residents. It means that the building phase is no longer regarded as a parenthesis in inhabitants' lives, but as an important opportunity for public expression and civic participation seen as a condition for sustainable and efficient housing rehabilitation. Conceptually, the building site is no longer seen as a no man's land and a temporary phase in the life of the neighbourhood but as a dynamic episode in the lives of the inhabitants.

Concretely, the architects immersed themselves in the Stephenson neighbourhood by locating part of their office in an old electronics workshop. This daily presence changed relationships with inhabitants and other stakeholders as well as the architects' perception of the initial architectural scheme, by setting it against the habits and needs of everyday life. They knew whom to contact for any daily issues on the building site. The electronics workshop was also transformed into a public space where a large model of the urban project was reconstructed for the inhabitants. Several meetings with residents, elected representatives, technicians from local authorities and representatives of local organisations were organised for presenting and discussing adaptation of the initial plan. Regular workshops and conferences were organised in the electronics workshop bringing together the current and future inhabitants and exploring topics such as making compost or recovering wastewater. Educational activities were also planned with children.

The new approach to the urban renewal project led to concrete and substantive changes for the community. Beyond the concrete rehabilitation or improvement of about 60 houses that should initially have been pulled down, the public exhibition and discussion of the large-scale model led to a change in the initial architectural proposal. Initially located just in front of some tall buildings planned for the eco-neighbourhood, the rehabilitation of small traditional houses presented the problem of a disproportionate scale and of perspective. A consensual agreement between all stakeholders has been reached based on the revision of the urban plan involving the progressive transition of the height of the buildings adjacent to the Stephenson neighbourhood. Moreover, the architects mediated discussions about the future of the cul-de-sac that the urban planners wanted to open to traffic, whereas families wanted to keep it as a secured space where children could run 
around and play safely. The compromise was to partially open the cul-de-sac, making it accessible to pedestrians and bikes but not cars. The construction of the first model of renewed housing that the residents agreed on was visited by present and future inhabitants. The idea was to meet and involve future residents in the district before they moved in.

The Ilot Stephenson project has also inspired and strengthened the governance of the whole urban renewal planning process. The semi-public company SEM Ville Renouvelée has adopted a participatory approach by implementing the eco-neighbourhood. Factors include the co-production of a sustainable development framework. Its formulation has not only involved the different local authorities and housing developers but also groups of local non-profit organisations called Collectif de l'Union. This group of local organisations and citizens demanded, from the beginning of the Union urban renewal plan, integration of employment, social and ecological aspects alongside the initial business and construction dimensions. Some collective proposals coming from local residents associations were formulated in 2010 to include grassroots projects and participation by inhabitants within the urban planning scheme. These claims, by degrees, took into account and partially impacted urban governance planning. Thus, the framework for the eco-neighbourhood adopted in 2007 was revised 4 years later in order to adjust to new needs expressed by local actors, local institutions' strategies and national legislation. Moreover, a charter of participation was drawn up with the different Union stakeholders. The active involvement of the group of local organisations led to the creation of a specific fund for resident participation by the local authorities in order to support local initiatives connected to the renewal urban project. Finally, the creation of a "House of the Union" has been inspired by the internal organisation and working methods used by the electronics workshop experiment. The Union group of local organisations has been put in charge of running the space.

\subsection{Internal Organisation and Working Methods}

As the Stephenson project has demonstrated, opening a building site can involve several innovative aspects in the architectural working methods. The most important aspect is the temporary establishment of at least one architect in the neighbourhood during the building or rehabilitation phase. This new architectural position means a form of commitment in the community beyond a simple technical role. Concretely, part of the architects' firm is established in the district, which is considered as a place of work. This sort of architect's immersion has been pushed beyond working in the neighbourhood, like in the Stephenson operation, to actually living with the inhabitants, as has been the case in a similar rehabilitation of old working-class houses in Boulogne-sur-Mer on the west coast of the Nord-Pas de Calais region.

The presence of the architects' office implies the mobilisation of new professional practices and skills due to the fact that the architect and the development project are embedded in neighbourhood life. One of the results is the trend for tailor-made 
approaches to housing rehabilitation that take into account domestic situations. Far from the sort of standardised urban construction that requires the same building materials throughout, a normalisation of inhabited rooms as well as heating and insulation systems, the architect tries to adapt interior and exterior construction through a compromise between urban requirements and inhabitants' concrete needs. This can lead, for example, to the installation of a new wood stove that most of the families use rather than the heat pump initially planned by the social landlords. The idea is that new housing standards are not always more sustainable and efficient if they are too far removed from tenants' habits. The architects also play the role of political regulator and social mediator in relationships between the local authorities, social landlords and inhabitants. Gaining the trust of inhabitants and getting them to agree to interventions at their homes, especially in a contentious context, means avoiding inappropriate decisions that risk halting the operation. For instance, architects may have to negotiate a lower and more progressive rent increase with social landlords than originally planned for the renovated houses.

New working methods also mean interactions with professionals (social workers, social entrepreneurs, artists, volunteers, etc.) who are involved in the neighbourhood in order to organise activities for and with the inhabitants during the building period. To a certain extent, the architect becomes a kind of community developer by facilitating the creation of public spaces and open meetings, by organising visits and animations with children, by being in contact with social services or work integration enterprises to obtain better access to rights or work opportunities for residents, by encouraging the intervention of artists in cultural events on the building site, etc. An initiative mentioned as unusual for local urban planners has been the contribution of students from Tourcoing Beaux Arts School who created a temporary art performance within the houses under renovation. One example in Boulogne-sur-Mer has been the participation of a number of inhabitants involved in self-renovation of their homes in building skills training sessions that potentially open up new job perspectives to them.

In the case of Ilot Stephenson, the architects' presence also led to the involvement of local building artisans. This was facilitated by public procurement contracts divided into small batches, and the fact that the location of the architect's office at the building venue also changed the rhythm of professional interactions with construction workers who did not have to wait for the architect's traditional weekly visit to the building site for solving practical issues.

At the urban planners' level, the main change in working methods was the 2007 creation of a new statute of technician in charge of sustainable development and inhabitants' participation, introduced when management of the urban renewal project was transferred to SEM Ville Renouvelée. It is an innovation in a professional milieu dominated by architects and urban planners who are not used to and do not know how to work with groups of inhabitants, local organisations and neighbourhood councils. Urban planners have learnt to systematically present and discuss the urban project with residents within the different neighbourhood councils as well as on ad hoc committees. 


\subsection{Embeddedness in the Local Welfare System}

From a local political issue to an emblematic and publicised project, the Ilot Stephenson story has profoundly influenced the Tourcoing mayor, urban planners from SEM Ville Renouvelée and Lille Metropolis and other stakeholders in the project. It has definitely led to the integration of a human and participatory dimension in urban planning and urban renewal projects. According to the architects, calling into question, even if partially, the plan for a large and emblematic urban renewal project already voted in by the local authorities remains quite rare.

Although such innovations are quite sensitive to the local context, several factors can be identified for explaining why it has worked. Firstly, Ilot Stephenson, like the housing rehabilitation in Boulogne-sur-Mer, was considered a problematic zone within the initial urban renewal plan. Faced with deadlock situations such as residents' protests or the retrenchment of welfare services, local policymakers opened their minds to new ideas and agreed to explore new urban solutions. Consequently, the political will of the mayor was fundamental for long-term support for the architects in the face of scepticism expressed at the beginning by a number of social landlords, local urban planners and social workers. Secondly, the national reputation of the architect and his connections with the political network are another important factor, not only for launching such a specific experiment, but also for integrating and legitimizing it with networks, processes and resources from other scales. Thirdly, it is worth noting that the contract mechanism used for this experiment is also unusual for this kind of urban operation. Whereas local authorities usually turn to public procurement for urban planning projects, this was a partnership agreement (convention de partenariat), which provided the contractual frame between the architects' firm and SEM Ville Renouvelée. An adapted contracting mechanism is favourable to this sort of tailor-made urban project.

Finally, the Ilot Stephenson case is interesting because conceptualisation is an ongoing process, expressed by the slogan Faire ensemble, Le Grand ensemble ["Working together to build the whole urban area"], which has been tested successfully in other places, such as the rehabilitation of all the precarious housing on a street in Boulogne-sur-Mer. This ability of the Construire architects to transform local experiments within a specific context into a more or less mainstream concept is crucial for being able to influence collective representations of what is or is not innovative, and to become relevant to people and institutions from outside. Architects regularly conceptualise and communicate on a new urban approach to social housing construction and urban rehabilitation through publications, conferences and videos.

In addition, one of the architects who worked in the Stephenson neighbourhood throughout the entire project won a prize for young urban planners in 2012. The Ilot Stephenson project has been subject to local publicity and media coverage with a special website and numerous articles in the regional press. The inhabitants' organisation was often solicited by journalists. Stephenson has gradually become a kind of showcase project, with all the risks of overexposure in terms of expectations created. Whereas the Ilot Stephenson was a local political problem at the beginning of 
the 2000s, 10 years on, it has become an emblematic success promoted by the local authorities. Attention for the project goes far beyond the local community. Many professors and students of architectural schools, delegations of technicians from other cities and even international visitors have visited the building site and met the architects and urban planning team.

Open Access This chapter is distributed under the terms of the Creative Commons AttributionNonCommercial 4.0 International License (http://creativecommons.org/licenses/by-nc/4.0/), which permits any noncommercial use, duplication, adaptation, distribution and reproduction in any medium or format, as long as you give appropriate credit to the original author(s) and the source, a link is provided to the Creative Commons license and any changes made are indicated.

The images or other third party material in this chapter are included in the work's Creative Commons license, unless indicated otherwise in the credit line; if such material is not included in the work's Creative Commons license and the respective action is not permitted by statutory regulation, users will need to obtain permission from the license holder to duplicate, adapt or reproduce the material.

\section{References}

Bouchain, P., \& David, C. (2010). Construire ensemble, Le Grand ensemble. Paris: Actes Sud. Construire ensemble/Le Grand ensemble. http://www.legrandensemble.com. Accessed 9 Jan 2015.

Cahier de l'Union (2012). Stephenson, la renaissance inattendue d'un quartier ancien. http:// www.lunion.org/logement/la-rehabilitation-de-lilot-stephenson.html. Accessed 9 Jan 2015.

Donzelot, J., \& Epstein, R. (2006). Démocratie et participation, l'exemple de la rénovation urbaine. Esprit, 7, 5-35.

Fraisse, L. (2013). Social innovations in Lille, WP5, France. http://www.wilcoproject.eu/wp-content/uploads/2013/10/Lille_report-on-innovations.pdf. Accessed 9 Jan 2015.

Hall, S., \& Hickman, P. (2011). Resident participation in housing regeneration in France. Housing Studies, 26(6), 827-843. 